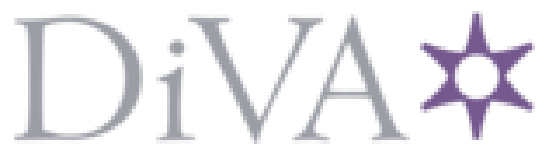

http://www.diva-portal.org

This is the published version of a paper published in .

Citation for the original published paper (version of record):

Frisk, L. (2002)

The Satsang Network: A Growing Post-Osho Phenomenon

Novo Religio: The Journal of Alternative and Emergent Religions, 6(1): 64-85

https://doi.org/10.1525/nr.2002.6.1.64

Access to the published version may require subscription.

N.B. When citing this work, cite the original published paper.

Permanent link to this version:

http://urn.kb.se/resolve?urn=urn:nbn:se:du-31618 


\title{
The Satsang Network
}

\section{A Growing Post-Osho Phenomenon}

\section{Liselotte Frisk}

\begin{abstract}
This article describes and discusses a phenomenon I call the Satsang network, a group of Westerners claiming to have reached enlightenment. Several of these persons spent many years with the controversial guru, Osho; hence, I argue that one way of understanding the Satsang network is as a post-Osho development in which satsang holders become an example of how charismatic leaders emerge from institutionalized religious movements. Also discussed are the construction, confirmation, and social support of the enlightenment process; the alteration of meanings when Eastern concepts are interpreted from a Western perspective; and ways in which certain core teachings in the Satsang network mirror key processes of current globalization.
\end{abstract}

A t the end of the 1990s, a Western new religious phenomenon gradually caught my attention. Several Westerners from different countries, announced as being "enlightened" or sometimes "awakened," were touring the world. Their main activity was to hold "satsang," ${ }^{1}$ or meetings aimed at helping others to make the transition to enlightenment. At first glance, it seemed that the enlightened persons operated independently of each other. There were no explicit relations between them, no organization, no membership. However, upon closer examination, I discovered that several of them had a history of intense involvement with the Osho movement.

Osho $^{2}$ (1931-90), or Bhagwan Shree Rajneesh as he was called previously, was the controversial Indian guru who built the town of Rajneeshpuram in Oregon, a largely rural area in the northwest United States, in the early 1980s. His main goal was to deprogram his disciples from all "isms" and belief systems. ${ }^{3}$ As he saw no difference between the

Nova Religio: The Journal of Alternative and Emergent Religions, Volume 6, Issue 1, pages 64-85, ISSN 1092-6690 (print), 1541-8480 (electronic). (C) 2002 by The Regents of the University of California. All rights reserved. Send requests for permission to reprint to: Rights and Permissions, University of California Press, Journals Division, 2000 Center Street, Suite 303, Berkeley, CA 94704-1223. 
world and the divine, ${ }^{4}$ he taught that there was no reason to renounce the material world. ${ }^{5}$ In Hinduism, traditional sannyasa involves world renunciation, but in the Osho movement sannyas ${ }^{6}$ is defined as spiritual renunciation; no outer changes are needed, only a changed mind. Therefore a sannyasin in the Osho movement does not need to, or even should not, renounce any desires. ${ }^{7}$

Osho died in 1990. After his death, some of his disciples began to visit Poonjaji (1910-97), affectionately called Papaji in honor of an Indian guru who had been a disciple of Ramana Maharishi (1879-1950). At the intersection of these two traditions, several of the former Osho disciples were said to have experienced "enlightenment" and became spiritual masters in their own right.

In this article, I first discuss the definition of the Satsang network, as I have chosen to call it, and then briefly describe its meaning system or "world" - the reality it inhabits. ${ }^{8}$ Then I discuss the development of this network considering theories of revival and reform following the death of the charismatic leader and institutionalization of new religious movements. I argue that at least one way of understanding the Satsang network is as a post-Osho protest and reform movement, with new charismatic leaders.

In the second and main section I focus on three related issues:

1. Enlightenment as a social process. I investigate how enlightenment is constructed, confirmed and supported through social processes. I argue that enlightenment can be understood as a redefinition of one's identity, similar to what happens in a conversion process.

2. The effects of migration on culture characteristics. I focus on some characteristics of Eastern origin in the Satsang network, and argue that as they are understood and interpreted from the perspective of Western culture, the meanings they had in the culture of origin changes.

3. The role of globalization. I argue that globalization is a prerequisite for the development of the Satsang network, and that certain core teachings mirror key globalization processes.

There are several enlightened Westerners in the international Satsang network. Counting only those visiting Sweden in 1999 and 2000, the number comes to more than a dozen. Many others are not coming to Sweden, but hold satsang only in other countries. ${ }^{9}$

In my investigation of the Satsang network, I focus on some of the enlightened persons who often visit Sweden: Vasant (male, Norway), Vartman (male, Australia), Susanna (female, Sweden), Shantimayi (female, United States), Rahasya (male, Germany), Arjuna (male, United States), Anamika (female, Israel), and Gopalji (male, Holland). My sources include participant observation, interviews and material on the different Internet homepages of the enlightened persons. 


\section{THE SATSANG NETWORK}

\section{Definition}

The Satsang network has no organization of the traditional kind. It has no name. The term "Satsang network" is my own invention. It has no explicit borders as to exactly which spiritual teachers are included and which are excluded. The majority of the satsang holders have a relation to the Osho movement, many of them also to the tradition of Poonjaji, but some are unrelated to either of these. I have three reasons for treating these teachers together.

1. It is clear from their teachings, vocabulary, and references to certain Eastern spiritual teachers that there are interconnections among them. The three Eastern gurus at the center are Osho, Poonjaji (with connections to Ramana Maharishi), and Sri Swami Hans Raj Maharaj in Rishikesh, the only one presently living, born around 1925. ${ }^{10}$ These three gurus are related only through their followers, the enlightened Westerners, who often refer to at least two of them simultaneously. Western spiritual lineages have also developed; enlightened Westerners themselves have disciples, who in turn have their disciples. At least two Western women and one man, Gangaji, Shantimayi, and Tyohar, have generated their own lineages of enlightened Westerners. ${ }^{11}$

2. The enlightened Westerners are also interconnected in that many of their (unenlightened) followers are followers of more than one of them and also accept the others as enlightened teachers.

3. Several of these Westerners tend to appear in the same places, sometimes at the same time, and seem to recognize each other as enlightened. It is quite common that they express respect and appreciation for each other. ${ }^{12}$

\section{The Core Teaching of Enlightenment}

The core teaching of the Satsang network is that enlightenment is here for everyone at the present moment. The only thing one need do to become enlightened is drop all concepts, ideas and beliefs, even about enlightenment, ${ }^{13}$ leave ego behind,${ }^{14}$ leave mind behind,${ }^{15}$ drop the idea of being unenlightened, that something is missing, ${ }^{16}$ and give up seeking. ${ }^{17}$ In this process, there is a total experience of everything as divine, ${ }^{18}$ and a willingness to embrace everything. ${ }^{19}$ Beyond the individual mind there is consciousness, nothingness, non-individuality, ${ }^{20}$ no sense of self, ${ }^{21}$ emptiness, ${ }^{22}$ and God or the divine..$^{23}$ There is a clear emphasis that everyone is already enlightened-we only have to realize it. ${ }^{24}$ 


\section{Satsang-The Main Activity}

The sacred action above all in the Satsang network is satsang, a traditional activity in the Indian spiritual context, meaning "being with good/righteous companions." Satsang is a sitting together with an enlightened person who usually gives a short speech and then answers questions. All satsangs in the Satsang network are a bit different, each of the enlightened masters having developed his or her own satsang culture and style. However, I consider three features characteristic of the Satsang network:

1. Active participation of the audience. The questioner is invited to sit beside the satsang master, with a microphone, and take an active part in the dialogue. No matter what the original question is about-intellectual questions, if they happen to occur, are never answered but rather laughed at - the attention is soon focused on the questioner and her or his aspiration for enlightenment. The usual procedure, from a ritual perspective, often starts with the questioner talking about a personal problem, and the satsang master pointing to enlightenment as the solution. People talk about their most intimate feelings in front of the audience, sometimes crying or showing other strong emotions. It is natural that only verbally talented people, with no difficulty in speaking about personal matters, appear as questioners.

2. Entertainment and laughter. The satsang masters are all professional speakers, knowing how to make satsang a performance in high spirits. It is often great fun to sit in satsang. Sometimes people roar with laughter.

3. Music and dance. The network has its own musicians and composers; in fact, some of the satsang masters are composers themselves and might play a guitar and sing in the satsang, which can at times be interrupted by wild dancing, even by the satsang master. Music and dance are considered important methods of experiencing the present moment fully, dropping thoughts, mind and other unnecessary luggage. The music can be Western with words in English, or westernized Indian mantras.

\section{Satsang Holders: Enlightened Persons}

Gods are quite absent in the Satsang network. Functionally, however, the enlightened or awakened persons may be, for the participants, close to gods as defined by William E. Paden: "any superior being that humans religiously engage," or "points at which humans relate to "the other." ${ }^{25}$ Paden emphasizes that it is the relationship between the indi- 
vidual and the god that makes the god.$^{26}$ Clearly, the enlightened persons occupy a very special position in the network. They are considered to have reached the ultimate spiritual realization. They are the ones holding satsang. Photos, videotapes, and audiocassettes of some of them are sold to the satsang attendees.

At the same time, it is evident that many of the enlightened persons try to minimize their own importance. In satsang, not only "questions" are invited, but also "sharing." Some of the questioners (or sharers) may begin by stating something like, "I see enlightenment/God in you." This attribution is usually deflected by the enlightened person, who might say: "This is called projection. It is all inside you. We did this with Osho for many years" ${ }^{27}$; or, "Look inside, not at me. There is no transmission here, no guru." 28

Although the possibility of enlightenment by transmission is denied, clearly satsang must be expected to fulfill some kind of similar function anyway-somehow triggering enlightenment in the audience. Anamika says that her goal is to take others to "no mind" or enlightenment. She aims "to share with you your own potential. I cannot teach you. Only show myself." ${ }^{29}$ On the websites of enlightened persons, one reads testimonials such as the following:

People expressed again and again the gratitude they felt to Osho for having placed him [Vasant] in our way, for having awarded us with a gift that revoked the living presence of our beloved Master Osho. It was a real privilege for us to be able to have tasted the nectar of a direct satsang or darshan with a being of the carat of Osho. . . ${ }^{30}$

At many satsangs, despite the invitation to "share" and the important role taken by the audience, there seems to be a tendency to mock the questioners, an approach which makes the questioner get the worst of it in the dialogues. This is, however, not always the case. Some enlightened persons have a more compassionate and egalitarian approach than others.

\section{The World as Divine}

As in the Osho movement, the world is conceived as being divine. Everything is absolutely okay, because all is consciousness or God. ${ }^{31}$ We have to accept everything as it is. ${ }^{32}$ Arjuna defines enlightenment as the absolute willingness to embrace everything. ${ }^{33}$ There seem to be few external rules characteristic of many traditional religions. Several enlightened persons live with their boyfriends or girlfriends, some have children, and some are divorced. Alcohol and tobacco are not condemned. Nothing appears to be seen as "sinful." 


\section{The Satsang Network as a Post-Osho Development}

A religious movement may develop in different directions after the death of the charismatic leader, with difficulties depending upon what preparations have been made ahead of time. Leadership has to be passed on somehow. ${ }^{34}$ Perhaps the easiest solution is to install spiritual successors prior to the charismatic leader's death, although this solution has its own problems. ${ }^{35}$

However, the death of the charismatic leader and transition to another power structure always has potential to be problematic for a religious movement. Max Weber related the death of the charismatic leader to the transition from the charismatic structure to the rational or bureaucratic structure. Typical of the charismatic structure is its instability and transitory nature; it has to change towards a rational form and a bureaucratic structure. Normally, this change happens when the charismatic leader dies. ${ }^{36}$

This development can be seen in the Osho movement. After the death of Osho, there was no longer a charismatic leader. A group of 21 persons handled the administrative leadership and thus stabilized the movement, which then lost a certain amount of spontaneity and creativity. As Thomas O'Dea observed, a development like this often leads to new movements of protest and reform with new charismatic leaders. ${ }^{37}$

Institutionalization in the Osho movement, however, began before Osho left his body, and it expressed itself in several ways. For example, all authorized Osho centers around the world were standardized and had to conduct certain kinds of meditation at specified times of the day. An important but obstructive prerequisite for participation in any activities was certification that one was free from the HIV virus. ${ }^{38}$

According to Osho's teachings, anyone may become enlightened. Everyone is in fact born enlightened but dies unenlightened because of the programming of society, religion, and culture. In meditation the ego disappears, and the individual becomes part of the universe, part of existence itself. ${ }^{39}$ However, in practice only Osho is considered to have reached enlightenment. Spiritually he has no successor.

The development of the Satsang network, therefore, created a difficult situation for the Osho movement. Besides not having the complicated regulations of the Osho movement, the Satsang network supplied living charismatic leaders. Some recently enlightened persons previously were well-known therapists in the Osho movement who used to travel the world leading therapy groups at Osho centers. One of them, Rahasya from Germany, declared his awakening and then wrote to the world center in Poona offering his services. Part of the response from Poona reads: 
Regarding the Multiversity, we have clear guidance from Osho: The Multiversity, and any groups at Osho places, are for therapy and other techniques to help clear the ground for meditation-not for spiritual teachings. [...] As we see it, this is entering the domain of "the spiritual" and precisely the role of "spiritual guide, teacher, master." The "spiritual role" in Osho places is already full-we don't have any needs or vacancy there. [ ... ] Spirituality is Osho's work. He has made it clear that he needs no help in this - in fact, that we have to stay out of it. His effort is to leave us alone with meditation, with no mediator between the meditator and existence. In addition to the above is the situation that along with Osho, you are publicly and in professional correspondence acknowledging Gangaji ${ }^{40}$ as contributing to your present state. Associating yourself with another spiritual guide in this way means that you no longer qualify to represent yourself as an "Osho therapist" or to use the title Osho professionally in any way. ${ }^{41}$

\section{Rahasya answers:}

$[\mathrm{T}]$ here is a new situation to respond to, that has never been there before, but that has been predicted by our beloved master, when he was saying that hundreds of his disciples will awaken. I am sure that he never meant to keep these people "out." [ . . . ] You ask me to not use the title Osho professionally in any way. Beloveds. Since I met Osho in 1980 and he allowed me to become his therapist in 1983 I stopped making a difference between my private life and my "profession." Everything that this body-mind called Rahasya lived since then, and more and more up until today, is OSHO. Everything that I was teaching as an Osho therapist, exploring on my spiritual journey, and now still teaching as a flower of Osho that has awakened, is Osho. If you ask me not to use Osho professionally, I am very sorry, I cannot lie or deny him just because I do not fit into the institution of Osho which does not have space for his flowers. For me Osho is not and [sic] institution, he is not that small. As I heard him say he is dissolved in HIS people. Yes, now more than ever. When people meet me, they still meet Osho, before Rahasya's awakening and after even more, what can I do? Except shedding tears of gratefulness. Yes, I agree that I am not an Osho therapist anymore, perhaps we have to create a new title-if a title is needed at all: An "Osho flower." But I am totally fine with no title. [ . . . ] Beloveds, pleeeease do not let Osho become a church, it will not work anyway with so many friends awakening, it will be a self destructive device. . . ${ }^{42}$

By 2000, many Osho centers all over the world were closing because of faltering interest. The Satsang network, however, was growing.

\section{ENLIGHTENMENT FROM THE PERSPECTIVE OF SOCIAL PROCESSES}

Different social realities are constructed, confirmed and supported through social processes. The truth of the state of enlightenment may 
not be possible to investigate. It is possible, however, to discover the ways in which enlightenment is conceptualized and retold, as well as the different ways in which a group supports the enlightened person. Below, I focus on some of the social processes related to the realization of the enlightened state in the Satsang network.

\section{The Retrospective Story of Enlightenment}

The stories of enlightenment-or awakening as it is sometimes called $^{43}$ — are often surprisingly vague. In the case of Arjuna, for example, his website simply says:

This search found its fruition in 1991, when Arjuna met his teacher, H. W.

L. Poonjaji in India who pointed Arjuna's attention back to the immediate availability of the Self in this very moment. Arjuna lived with his teacher for a year, and in 1992 Poonjaji asked him to return to the West to share this "open secret." 44

In satsang Arjuna explains a little further: "When I met Papaji something unnecessary - a kind of seeking-dropped. What was left had always been here." 45

Concerning Vasant, the information is not much more detailed. His website says that in 1991, after Osho passed away, he experienced a profound inner transformation:

I was no more the one I was yesterday. I had no identification with any personality or ego. The whole past was gone. I was "drowned" in peace, in a deep spaciousness and silence. This was the climax of seeking, the flowering of sannyas, now whatever happened was in the hands of Existence, God. ${ }^{46}$

Anamika is advertised as being enlightened. It is said that a 1997 traffic accident gave her a first insight, and that the realization was completed later that year when she met her master Tyohar. ${ }^{47}$ Anamika says that she seldom wants to speak about her enlightenment, as this information cannot help others to the realization. ${ }^{48}$

In satsang, to a direct question whether he thinks he is enlightened, Vartman answers:

I can say yes and no in the same sentence. On 28 December 1997 there was a moment... . Since then I recognize consciousness. It is obvious since then that I am consciousness, and I see that everyone is pure consciousness. The seeking to become enlightened stopped..$^{49}$

About Gopalji, it is said on his website: 
The day he became forty years old, during his first therapy-group with an Osho therapist, his heart exploded and he knew immediately that "that" was what he truly had been looking for all of his life. During his second group he came into a state of samadhi for the first time: "All contractions disappeared. It was as if I stepped out of my cage: straight from hell to heaven!" This experience lasted about eight months. . . In 1996, at the feet and through the grace of his Master [Swami Hans Raj Maharaj], awakening happened.$^{50}$

As we see, enlightenment is mostly described as one or a series of inner experiences, sometimes very exactly dated. For several of the enlightened persons, the spiritual teacher seems to have been an important catalyst. However, the experience itself, or the circumstances in which it happened, is never much described. Maybe it is too private, or seen as not helpful for the audience. A description of enlightenment could be a barrier for it to happen, or the enlightened persons could have the same problem of describing mystical experiences as many wellknown mystics. Language has its limitations.

Straight questions about whether satsang holders really consider themselves enlightened, and about the details of their enlightenment, rarely occur in satsang. However, questions of this sort sometimes are asked, mainly by people who have not yet learned the culture. ${ }^{51}$ Sometimes the question is avoided,$^{52}$ but, sometimes it is answered.$^{53}$ When answered, a straight "yes" is seldom given. It is emphasized that there has occurred a moment after which everything has changed, a waking up from a dream, ${ }^{54}$ but also that even enlightenment is not an unchangeable state, ${ }^{55}$ and that even a person who has gone through this change still needs other people as teachers and mirrors. ${ }^{56}$

\section{Redefining Oneself as Enlightened}

The core teaching of the Satsang network is that we are enlightened already. We only have to drop thinking that we are not. Arjuna said in one satsang that he once said to Poonjaji, his guru, that he did not feel totally awakened but only in the process, and Poonjaji answered that he should never speak or think like that again. "And it was so strong that I have never picked up this thought again." 57

From a sociological perspective, it is clear that becoming enlightened means a redefinition of one's identity. According to Meredith McGuire, "the individual locates himself in a larger social order by means of his meaning system. The meaning system informs the individual what ' $k$ ind' of person one is, the importance of roles that one performs, and the significance of being who one is. A meaning system makes sense of one's identity and social being." ${ }^{58}$ Redefining oneself as enlightened therefore gives a strong sense of new identity, such as that 
which emerges in a conversion process. The conversion process involves resocialization, partly consisting of a reshaping of the identity of the individual. ${ }^{59}$ Thus, identifying oneself as enlightened could also be seen as internalizing a new identity.

\section{Declaring and Confirming Enlightenment}

How do you let others know that you have become enlightened? Is it necessary to let others know?

There might be a number of enlightened persons in the network who do not hold satsang or are known in other ways, considering the relative ease of becoming enlightened and the emphasis on the possibility that everyone may become enlightened. In satsang I have witnessed several questioners who indicated they have had experiences of enlightenment.

There are, however, different ways to make enlightenment known. Rahasya, the former Osho therapist, simply announced his awakening by a fax sent to all Osho centers in the spring of $1999 .{ }^{60}$ But the most common way to make enlightenment known is that a recognized enlightened person confirms another's enlightenment in satsang. If this happens, the enlightenment is known in larger circles right from the beginning. This is often how it happened to the satsang holders themselves. Many of them had their enlightenment confirmed by their spiritual master. For more experienced satsang holders, the master is normally Poonjaji or Sri Hans Maharaj. For the less experienced, it could be one of the older Western satsang holders. For example, in a satsang in the summer of 1999, Susanna was confirmed by Vartman to be enlightened and after that started to hold satsang herself.

In the summer of 2000 I witnessed one person being confirmed to be enlightened in Arjuna's satsang. It seemed that this person realized enlightenment in that very moment. Arjuna invited people to make the decision not to postpone enlightenment, to decide for enlightenment now. One woman, a disciple of Osho, chose "no" and went down from the stage. The next person, a woman who just laughed and threw herself on Arjuna's neck, where she stayed in a hearty embrace while music played, never said a word, and it was up to the audience to guess if the embrace was an expression of enlightenment or not. But the third, a man who said he was completely on fire, looked into Arjuna's eyes and, shaking, dropped the microphone.

ARJuna: "Look inside, not at me. There is no transmission here, no guru.

What do you see?"

Questioner: "There is no one here."

ArJuna: "No, there is no one. This is truth. Find the edge!"

Questioner: "There is no edge."

ArJuna: "When did it begin?" 
QUestioner: "It was here always."

ArJunA: "This is called realization!"

I was struck by the formalized, almost ritualized, language. It was apparent that the questioner and the satsang holder were moving in the same symbolic universe, talking the same language, maybe following a more or less given pattern.

\section{Sustaining and Supporting Enlightenment}

After the experience of enlightenment comes the challenge of keeping this state. Arjuna clearly states: "After awakening comes the challenge to live life from total freedom. External events are never intrinsically painful/pleasureful. It is the reaction to the external event which is." ${ }^{1}$

Clearly, there is an awareness of the importance of redefining one's identity continually to keep the enlightenment. To the man who became enlightened in satsang, Arjuna advised: "You may not feel this way always. There will be moments of ups and downs. This is life."62

According to Meredith McGuire, group support in the conversion process is important to affirm the new self and meaning system. ${ }^{63}$ The same could be said about enlightenment. I was present at one of Susanna's first satsangs, and it was evident that she was strongly supported by several questioners/sharers in satsang. Comments such as, "[y] ou really fill up that place [as a satsang holder]," and " $[y]$ ou do this so well" were common. ${ }^{64}$

\section{GULTURE MIGRATION AND GHANGES IN A NEW CONTEXT}

Religions always change when they migrate to another culture. Historically, different forms of Buddhism, Islam, and Christianity developed as these religions spread to new cultural areas. Some parts of the religion, which go well together with the new culture, become more emphasized, and often also change with reinterpretation, while other parts, which do not go well with the new culture, fade into the background. In the translation of a specific religion to another culture, there is always an element of interpretation. A translation-of the language and the religion-can never be made literally. Something from the original is always lost, and something new is created..$^{65}$ The satsang network is the result of a process of translating an Eastern religion into a contemporary Western culture.

\section{Eastern Religion Translated into Western Culture in Historical Context}

Eastern religions started to become more widely known in Europe 
at the end of the eighteenth century, when the first translations of Asian scriptures appeared in the West. During the nineteenth century, Eastern religions slowly began to influence Western religiosity in different forms, the most well-known being Theosophy. Even in the beginning of the twentieth century, few Eastern teachers were available to Westerners, and there were few Eastern spiritual organizations in the West. ${ }^{66}$ One of the first, however, was the Hindu Vedanta movement initiated in the United States in 1893 by Swami Vivekananda (1863-1902) ${ }^{67}$ Otherwise, a viable option for those interested was to go to the East. The Englishman Allan Bennett was one of the first Westerners to enter the Theravadin sangha in Burma in 1902. ${ }^{68}$

From the period after World War I to the end of World War II, several Eastern teachers came to the West. One example is Swami Yogananda (1893-1952), who founded the Self-Realization Fellowship (SRF) in the United States in $1920 .^{69}$ During this period, also, the number of Westerners entering Eastern traditions in Eastern countries, including India and Japan, increased. ${ }^{70}$

Not until after World War II did Westerners start to become established as teachers in Eastern religions. In 1950, Lama Anagarika Govinda (Ernst Hoffman, Germany), the first Western teacher of Tibetan Buddhism, accepted a handful of Western pupils. Swami Yogananda was succeeded, after his death in 1952, by two Americans, and there were also a number of other Western teachers teaching the kriya yoga of Yogananda outside the organizational fold of the SRF.71

After 1963, the Eastern traditions blossomed as new religious movements in the West. ${ }^{72}$ Andrew Rawlinson, former lecturer in Buddhism at the University of Lancaster, emphasizes that this could not have happened without the preparation during the previous $70-80$ years. Now, he says, Westerners are at the heart of all Eastern traditions and are extending them..$^{73}$ This development is, I think, exactly what we see in the Satsang network.

\section{The Satsang Network:}

\section{Eastern Features Translated into Western Culture}

Essential features in the Satsang network have their origins in the Indian advaita (nondual) philosophy. In the migration of cultural elements from one culture to another, it is natural that features that make sense in the new culture are emphasized, but as they are understood and interpreted from the new culture's perspective, the meaning they had in the culture of origin may be altered. I will now examine some features of Eastern origin in the Satsang network, and focus on how they may have been reinterpreted in the Western context, and why.

One essential feature in the Satsang network is the concept of the sacred self, expressed as "consciousness," "nothingness," "emptiness," or 
"God within the human being." According to advaita, the innermost being of the person is divine, of the same identity as brahman, the supreme power and absolute reality in the universe. In the meeting with the West, this teaching had to interact with the Western secular understanding of the human self. Much under the influence of twentieth-century psychological currents, Western value of the individual human being has grown tremendously. At the intersection of Eastern and Western cultures, personal development has achieved ultimate importance. The core teaching in the Satsang network is to leave the personal mind behind, but in practice this teaching may seem ambivalent because stress is also placed on intense experiences, intimate relations, and therapeutic work with, for example, one's "inner child" or different problem-solving methods like Byron Katie's "The Work." ${ }^{4}$ The sacred self has, to a certain extent, become the sacred individual personality (as also in the Osho movement and different New Age orientations, for many of the same reasons).

Another important feature in the Satsang network, salient in advaita philosophy as well as Zen Buddhism, is the emphasis that enlightenment is already here: we only have to realize it. Traditionally, however, this has not been considered an easy process, and enlightenment is usually not considered to have happened very often. George D. Chryssides touches on this subject when he notices that Western Buddhists often aspire to nirvana, the final liberation, while this is seldom the case in the East, where other religious goals are emphasized. Chryssides suggests that the notion that one should spiritually aim for the top is characteristic of Christianity. Salvation, eternal life, or the kingdom of God are in Christianity not goals reserved for a few adepts, but for all. Therefore, it seems reasonable for the Westerner to aim at achieving the highest aspiration. ${ }^{75}$ The Satsang network could be interpreted in the same light. The ease of realizing enlightenment in the Satsang network is striking. Watching the individual becoming enlightened in Arjuna's satsang, I noticed similarities to Christian, especially Evangelical, environments.

Spiritual aspirations in India are often associated with world renunciation, although a few people also combine householder lives with spirituality. In the West, however, especially in Protestant countries, world renunciation has no historical tradition at all. In combination with more secular cultural features and material abundance during the last decades, an ideal of world renunciation has for most Westerners seemed increasingly absurd. Contemporary religious movements proclaiming world renunciation do not meet much success. In the Satsang network, all the enlightened persons live "in the world." The possibility of world renunciation or celibacy is not even discussed.

Finally, in the East there has always been a traditional hierarchical 
relationship between spiritual teacher and disciple. When Eastern movements migrated to the West, this feature was subject to much criticism. "Guruism" was never popular in mainstream Western culture, where equality, democracy, and equal rights for everyone have been indisputable values. In the Satsang network, the enlightened masters are still there, but the notion that everyone is already enlightened, and that there is no difference between the realized and the unrealized one, has practical implications which it never had in the East. As we have seen, satsang may involve more "sharing" than "questioning," and the enlightened persons are not always willing to play the role of guru. There is, however, ambivalence here: the whole concept of satsang builds on the notion that the enlightened persons can share something the others do not yet have. Still, the concept of equality is present in the Satsang network to a much greater extent than in Eastern contexts.

The concept of equality also has implications for the sex ratio in the Satsang network. Of the eight enlightened persons discussed here, three are female. Female spiritual teachers have traditionally existed to a much lesser degree in the East than in the contemporary West. As Eastern spiritual cultures migrate to the West, female spiritual teachers generally appear to a greater degree. ${ }^{76}$ Catherine Wessinger notes that the meeting of the Western social expectation of the equality of women and men, with a deemphasized male divine characterized by some imported Asian concepts of God, gives new opportunities for women to become religious specialists. ${ }^{77}$

\section{GLOBALIZATION}

Advanced communications in the modern world have given rise to the phenomenon of globalization, meaning the world is increasingly considered "one place" with an increasing flow of meanings, people, and goods between different regions. ${ }^{78}$ Globalization has affected religion in many important ways, one of which is the growth of so-called transnational cultures without a clear anchor in any one territory. The Satsang network is an example of this.

\section{The Combining of Different Traditions}

Andrew Rawlinson claims that there is a Western expression of Eastern religious teachings, and that two related features are characteristic of this development.

1. Concerning, for example, Buddhism, there are many particular traditions in the East with little reference to other Buddhist traditions. In the West, however, there has been a tendency to attempt to create a gen- 
eral, universal Buddhism, with little concern for the different particular traditions..$^{79}$ An example is the non-traditional vipassana sangha, made up of an international group of Western teachers of vipassana meditation. The vipassana sangha is almost an entirely lay phenomenon, not following any set of rules, and a relatively high proportion of the vipassana teachers are women, a phenomenon unthinkable in the Theravada tradition. ${ }^{80}$ Perhaps this tendency can be seen as picking only that which, from the Western perspective, seems important and appears to unite the Buddhist traditions. From other cultural perspectives, this way of practicing Buddhism may be completely unacceptable.

2. In the West, several of the Eastern religious traditions appeared in the same place, and because of that they could easily be compared ${ }^{81}$ Therefore Westerners are making comparisons in a way Easterners did not. This situation has, according to Rawlinson, given rise to "experiential comparative religion." ${ }^{2} 2$ Experiential comparative religion can exist as a genuine movement only in a place where there are enough religious traditions to experience in the first place. ${ }^{83}$ Westerners are asking questions of the Eastern traditions because the coming together of these traditions is occurring in the West. But far more significant, it is Westerners who are answering these questions as well. Westerners know from their own experience that several traditions can work side by side, and they put them together. ${ }^{84}$ "Experiential comparative religion" can, of course, be said to have existed wherever religions meet, but never so much as it does in the contemporary globalized world.

Irving Hexham and Karla Poewe discuss this as well when they remark that new religions consist of fragments of different traditions, and that new religions selectively combine aspects of many traditions to create new cultures. Hexham and Poewe also note that in new religions several cultures coexist "in the individual experience." $\$ 5$

Increasingly dense contacts between different cultures, or growing globalized conditions, may have different outcomes, but one of the most important outcomes is universalist tendencies. This was demonstrated to a great extent by some of the Western and Eastern religious movements already during the nineteenth and twentieth centuries, and was continued by the Osho movement in the 1970s. Osho was well known for talks and lectures inspired by different religious traditions, pointing to different religions as different ways to the same spiritual goal.

In addition to universalist assertions that there are no distinctions between any of the religions, in the Satsang network there is a mixture of elements from different religions to an even greater extent than in the Osho movement. Apart from blending with portions of Western culture, elements from different religions (mainly Hinduism and different Buddhist traditions) are mixed to the extent that it would be clear to few people visiting the websites of the enlightened masters that there 
is a mixture. On the website of, for example, Shantimayi, Hindu and Buddhist concepts appear side by side. Besides being initiated by a Hindu guru and teaching the Hindu Gayatri mantra, Shantimayi uses Buddhist terms and refers to Buddhist scriptures. ${ }^{86}$ Bhajans-Hindu devotional songs - are defined as songs from many spiritual traditions ${ }^{87}$ Norwegian sociologist of religion Pål Ketil Botvar speaks about "unconscious syncretism" as occurring when people combine elements from different religions without knowing or caring from which religion they come, and thus they are not aware of any contradictions. ${ }^{88}$ Thus new traditions are created with little awareness of origins. I think the Satsang network is developing so as to become an example of this. Several of the enlightened persons practiced Buddhism before they became enlightened and thus have personal experiences in more than one religion. ${ }^{89}$

\section{The Importance of Relativization}

One of the key terms of globalization is relativization. Globalization sets particular societies in a wider system of societies, resulting in the relativization of both societies and individuals. In a globalized context, the norms and values institutionalized within a particular society face the different images of the good society presented by other societies in the world. The global social reality relativizes all particular cultures, including, of course, the religions that form parts of these cultures. Individuals form their religious identity in the knowledge that their religion is only one among several possibilities. ${ }^{90}$

The consequence is that the plausibility not only of the traditional religions, but of all religious beliefs, is undermined. This leads, firstly, to a decrease of engagement in traditional religion because it is relativized and can no longer be seen as the absolute truth. Secondly, relativization can be seen as one of the main causes of the great amount of "don't know" and "partly true" answers regarding worldview questions documented in many quantitative studies all over Europe in recent years. In these studies, a great deal of uncertainty regarding beliefs is manifested, but also, I think, an orientation away from "belief religion." People do not believe in religion in the same way as before. ${ }^{91}$ "Beliefs" are more conceived as possibilities, "could-be-true." This tendency is probably supported by electronic technology where reality and fiction join in "virtual reality." There are today many realities, not only one.

In the Satsang network, the core teaching is that beliefs should be left behind (at least beliefs of a more traditional kind). Besides the core myth of the possibility of enlightenment for everyone at the present moment, no specific beliefs are encouraged. Nothing can be known as truth. Instead, there is a clear emphasis on personal experience. I think 
this characteristic of the Satsang network illustrates a paradigm shift in contemporary religion, from belief to experience.

\section{A Global or a Western Culture?}

The social anthropologist Ulf Hannertz remarks that transnational cultures are as a whole more marked by some territorial cultures than by others. Most of them are, according to him, in different ways extensions or transformations of the cultures of western Europe and North America and are organized so as to make people from western Europe and North America feel as much at home as possible (by using their own languages, for one thing).${ }^{92}$

In the Satsang network it is clear that, in spite of the mixture of traditions, only certain cultures are involved, and some cultures to a much greater extent. In Sweden, everything in the Satsang culture happens in English, a characteristic so natural that it is never even mentioned, for example, in the information pamphlets. There is no question of translation.

It is clear that certain cultures do not take part in the Satsang network. Examination of the enlightened persons' travel schedules published on the Internet shows that Europe (especially western and southern Europe), the United States, Australia, certain parts of Asia (India, Japan) and certain parts of South America (Brazil, Chile) are represented. The whole of Africa is absent, as are the Arab countries.

\section{CONCLUSION: NEW RELIGIOSITY IN THE CONTEMPORARY WESTERN GULTURE}

In this article I have investigated the Satsang network, a new religious phenomenon visible in the West from the 1990s, and discussed a way of understanding this phenomenon as a post-Osho development, illustrating how new charismatic leaders arise from an institutionalized religious movement. I also discussed the understanding of enlightenment within the network, and found that redefinition of one's identity and social support and confirmation may be seen as important parts of the process.

Next, I focused on some characteristics of Eastern origin in the Satsang network, and found that the meanings they had in the culture of origin were altered as they were interpreted from the perspective of Western culture. Examples of these were the alteration of the sacred self to the sacred individual personality; the understanding of achieving enlightenment as a quick and simple process, in expression strikingly similar to Evangelical conversion; the value of world renunciation fading into non-existence under influence of Western materialism; and 
the understanding of the relationship between the enlightened person and others as non-hierarchical.

Finally, I discussed globalization as a prerequisite for the development of the Satsang network, pointing to its universalist and syncretic tendencies. I argued that the global social reality relativizes all particular cultures, thus undermining the plausibility of all religious beliefs. In contemporary religions there is generally a shift from "belief-thinking" to "possibility-thinking," opening to different possibilities of existential matters, not adhering to specific beliefs.

Alver, Gilhus, Mikaelsson, and Selberg note a contemporary blending of religion and other areas, a blending between sacred and profane. The postmodern self no longer seeks sacredness and freedom from sin, but rather an experience of excitement, closeness, and fantasy. ${ }^{93}$ This could well describe the Satsang network. Satsang is both entertainment and emotional closeness, making it difficult to locate a border between sacred and profane. Religion today may be seen, in the wording of these authors, to be "thinly spread all over." ${ }^{94}$ Religion, as in the Satsang network, may be present in all parts of life-but thinly, without demands or great investments-and possible to combine with virtually anything else.

\section{ENDNOTES}

1. Satsang is a traditional activity in the Hindu context, sat meaning "good, true, truth, being" and sangh meaning "community." In the Satsang network, satsang is usually translated as "meeting in truth."

2. From 1989, Bhagwan Shree Rajneesh was called "Osho," which is the Japanese pronunciation of the Chinese characters meaning "monk." According to representatives of the movement, the name also refers to "oceanic," which is explained as "dissolved into the sea."

3. Bhagwan Shree Rajneesh, From the False to the Truth: Answers to the Seekers of the Path (Cologne: Rebel Publishing House, 1988), 319.

4. Bhagwan Shree Rajneesh, Roots and Wings: Talks on Zen (Poona: Rajneesh Foundation, 1975), 31.

5. Bhagwan Shree Rajneesh, The Book of Secrets: Discourses on "Vigyana Bhairava Tantra, "vol. 1 (Poona: Rajneesh Foundation, 1974), 29.

6. Hindi for Sanskrit sannyasa.

7. Bhagwan Shree Rajneesh, I Am the Gate, 3d ed. (Poona: Rajneesh Foundation, 1976), 45.

8. William E. Paden, Religious Worlds: The Comparative Study of Religion (Boston: Beacon Press, 1994), 7.

9. I find it impossible to estimate the total number of satsang holders. However, an email questionnaire distributed to 356 Swedes receiving Satsang Newsletter biweekly asked recipients which enlightened persons were important 
to them. The 82 respondents gave 49 different names, including Jesus and Sathya Sai Baba, but most referred to satsang holders in the Satsang network.

10. Personal communication with a disciple of Shantimayi, May 2001.

11. It is not clear to what extent these lineages could be considered paramparas in the Hindu sense. As far as I know, there is no consideration of transmission of spiritual authority, and no designation of guruship to certain successors (as for example in Siddha Yoga). See Catherine Wessinger, "Woman Guru, Woman Roshi: The Legitimation of Female Religious Leadership in Hindu and Buddhist Groups in America," in Women's Leadership in Marginal Religions: Explorations Outside the Mainstream, ed. Catherine Wessinger (Urbana: University of Illinois Press, 1993), 127. The role of the enlightened master seems to be much looser in the Satsang network than in traditional Hinduism.

12. There are also a few enlightened Westerners who are exclusive and do not accept others as enlightened; therefore, I do not include them in the Satsang network. One example is Andrew Cohen, an older disciple of Poonjaji, who in many ways is working with the same terminology as the others, but only within his own organization, which is called International Fellowship for the Realization of Personal Enlightenment. See <http://www.andrewcohen.org / >

13. Satsang with Anamika, Ängsbacka, Sweden, 1 July 2000.

14. Satsang with Vasant, Ängsbacka, Sweden, 3 July 2000.

15. Satsang with Anamika, Ängsbacka, Sweden, 2 July 2000.

16. Satsang with Arjuna, Ängsbacka, Sweden, 5 July 2000.

17. Satsang with Rahasya, Ängsbacka, Sweden, 3 July 2000.

18. Satsang with Vartman, Ängsbacka, Sweden, 1 July 2000.

19. Satsang with Arjuna, Ängsbacka, Sweden, 4 July 2000.

20. Satsang with Vartman, Ängsbacka, Sweden, 2 July 2000.

21. Satsang with Anamika, Ängsbacka, Sweden, 1 July 2000.

22. Satsang with Arjuna, Ängsbacka, Sweden, 4 July 2000.

23. Satsang with Anamika, Ängsbacka, Sweden, 1 July 2000.

24. Satsang with Vartman, Ängsbacka, Sweden, 2 July 2000.

25. Paden, Religious Worlds, 121-22.

26. Paden, Religious Worlds, 124.

27. Satsang with Rahasya, Ängsbacka, Sweden, 3 July 2000.

28. Satsang with Arjuna, Ängsbacka, Sweden, 5 July 2000.

29. Satsang with Anamika, Ängsbacka, Sweden, 1-2 July 2000.

30. Darshano, “An Osho's Gift from Norway to Brazil,” July 1999, <http:// www.vasantswaha.net/_from_old_site/letters_sacred_english.htm >. English is apparently not the writer's first language.

31. Satsang with Vartman, Ängsbacka, Sweden, 2 July 2000.

32. Satsang with Vasant, Ängsbacka, Sweden, 2 July 2000.

33. Satsang with Arjuna, Ängsbacka, Sweden, 4 July 2000.

34. J. Gordon Melton, "Introduction," in When Prophets Die: The Postcharismatic Fate of New Religious Movements, ed. Timothy Miller (Albany: State University of New York Press, 1991), 1-12. 
35. See for example Gene R. Thursby, "Siddha Yoga: Swami Muktananda and the Seat of Power," in Miller, When Prophets Die, 165-181, and Steven J. Gelberg, "The Call of the Lotus-Eyed Lord: The Fate of Krishna Consciousness in the West," in Miller, When Prophets Die, 149-164.

36. Max Weber, Max Weber on Charisma and Institution Building (Chicago: University of Chicago Press, 1968), 18-77.

37. Thomas O'Dea, "Five Dilemmas in the Institutionalization of Religion," Journal for the Scientific Study of Religion 1, no. 1 (1961): 30-39.

38. In the middle of the $1980 \mathrm{~s}$, Osho predicted that AIDS would annihilate two-thirds of the world's population before the year 2000. He also introduced rules for his disciples regarding how to avoid contamination. See James S. Gordon, The Golden Guru: The Strange Journey of Bhagwan Shree Rajneesh (Lexington, Mass.: Stephen Greene Press, 1987), 131-34. The official explanation for requiring certification of HIV-negative status to participate in Osho activities was that Osho thought that the methods of the disease's transmission were not clear. He thought it might be transmitted by sweat or tears, which might be expressed during physically and mentally exhausting parts of meditation. (Interviews with representatives from the Osho movement on several occasions.)

39. Rajneesh, From the False to the Truth, 44-186.

40. An American enlightened woman who is a disciple of Poonjaji.

41. <http://globalserve.net/ sarlo/Ypunepolitix.htm>, accessed 10 December 2001 .

42. <http://globalserve.net/ sarlo/Ypunepolitix.htm>, accessed 10 December 2001 .

43. Vartman says, for example, that awakening is a better word than enlightenment (Satsang, Ängsbacka, Sweden, 2 July 2000). Concepts are seen as something negative in the Satsang network, and of course enlightenment itself is a concept, therefore, sometimes the term is not used.

44. "Biographical Notes from Arjuna Nick Ardagh," <http://www.living essence.com/aBio.htm>, accessed 10 December 2001.

45. Satsang, Ängsbacka, Sweden, 4 July 2000.

46. "Vasant Swaha," <http://www.vasantswaha.net/>, accessed 10 December 2001 .

47. Advertisement at Ängsbacka kursgård, Sweden, 5 July 2000.

48. Personal conversation, Ängsbacka, Sweden, 5 July 2000.

49. Satsang, Ängsbacka, Sweden, 2 July 2000.

50. "About Gopalji," <http:// www.xs4all.nl/\% 7Egopalji / home.htm>, accessed 10 December 2001.

51. Satsang with Vartman and Susanna, Ängsbacka, Sweden, 2 July 2000.

52. Satsang with Anamika, Ängsbacka, Sweden, 1 July 2000.

53. Satsang with Vartman and Susanna, Ängsbacka, Sweden, 2 July 2000.

54. Satsang with Vartman, Ängsbacka, Sweden, 2 July 2000.

55. Satsang with Rahasya, Ängsbacka, Sweden, 3 July 2000.

56. Satsang with Vartman, Ängsbacka, Sweden, 2 July 2000.

57. Satsang with Arjuna, Ängsbacka, Sweden, 5 July 2000. 
58. Meredith McGuire, Religion: The Social Context, 3d ed. (Belmont, Calif.: Wadsworth Publishing Company, 1991), 31.

59. McGuire, Religion, 78.

60. Satsang with Rahasya, Ängsbacka, Sweden, 3 July 2000.

61. Satsang with Arjuna, Ängsbacka, Sweden, 5 July 2000.

62. Satsang with Arjuna, Ängsbacka, Sweden, 5 July 2000.

63. McGuire, Religion, 78.

64. Satsang with Susanna in Stockholm, Autumn 1999.

65. Catharina Eriksson, Maria Eriksson Baaz and Håkan Thörn," "Den postkoloniala paradoxen, rasismen och 'det mångkulturella samhället': En introduktion till postkolonial teori," in Globaliseringens kulturer: Den postkoloniala paradoxen, rasismen och det mångkulturella samhället, ed. Catharina Eriksson, Maria Eriksson Baaz and Håkan Thörn (Nora: Nya Doxa, 1999), 46.

66. Andrew Rawlinson, The Book of Enlightened Masters: Western Teachers in Eastern Traditions (Chicago: Open Court, 1998), 38-39.

67. Catherine Wessinger, "Hinduism Arrives in America: The Vedanta Movement and the Self-Realization Fellowship," in America's Alternative Religions, ed. Timothy Miller (Albany: State University of New York Press, 1995), 173-74.

68. Rawlinson, Book of Enlightened Masters, 4.

69. Wessinger, "Hinduism Arrives in America," 173-74.

70. Rawlinson, Book of Enlightened Masters, 43-54.

71. Rawlinson, Book of Enlightened Masters, 43-54.

72. See for example Gene R. Thursby, "Hindu Movements since Mid-Century: Yogis in the States," in Miller, America's Alternative Religions, 191-213.

73. Rawlinson, Book of Enlightened Masters, 56.

74. "The Work" is a written exercise consisting of four questions and a "turn-around" designed to clear the mind. See <http:// www.thework.com / >

75. George Chryssides, "Transcultural Migration and New Religious Movements: A Case Study of Western Buddhism," paper presented at the International Association for the History of Religions, Durban, South Africa, 5-12 August 2000.

76. Rawlinson, Book of Enlightened Masters, 7-11.

77. Wessinger, "Woman Guru, Woman Roshi," 125.

78. Ulf Hannertz, "Cosmopolitans and Locals in World Culture," in Global Culture, Nationalism, Globalization and Modernity, ed. Mike Featherstone (London: Sage Publications, 1997), 237.

79. Rawlinson, Book of Enlightened Masters, 39.

80. Rawlinson, Book of Enlightened Masters, 4-7.

81. Rawlinson, Book of Enlightened Masters, xviii.

82. Rawlinson, Book of Enlightened Masters, 35.

83. Rawlinson, Book of Enlightened Masters, 62.

84. Rawlinson, Book of Enlightened Masters, 97.

85. Irving Hexham and Karla Poewe, New Religions as Global Cultures: Making the Human Sacred (Boulder: Westview Press, 1997), 41-47. 
86. Shantimayi, "Non dualism and the Way of the Bodhisattwa, Bodhisacha-Part 3," 2000, <http://www.shantimayi.com/chapter1/teaching.html>, accessed 10 December 2001.

87. <http://www.shantimayi.com/ chapter1/denmark.html>, accessed 10 December 2001.

88. Pål Ketil Botvar, "Hvor individualisert er folkereligiositeten egentlig?" in Troen er los. Bidrag till å belyse forholdet mellom folkereligiositet, nyreligiositet og kristen tro, ed. L. G. Engedal and T. Sveinall (Trondheim: Tapir forlag, 2000).

89. See for example "Gangaji," <http://www.gangaji.org/satsang/library/ lineage.htm>, accessed 10 December 2001.

90. Peter Beyer, Religion and Globalization (London: Sage Publications, 1994), 9, 26-27, 30.

91. Paul Heelas, Religion, Modernity and Postmodernity (Oxford: Blackwell Publishers, 1998), 5.

92. Hannertz, "Cosmopolitans and Locals in World Culture," 244.

93. Bente Gullveig Alver, Ingvild Saelid Gilhus, Lisbeth Mikaelsson, and Torunn Selberg, Myte, magi og mirakel $i$ möte med det moderne (Oslo: Pax Forlag, 1999), 14-15.

94. Alver, Gilhus, Mikaelsson, and Selberg, Myte, magi og mirakel i möte med det moderne, 8 . 